AGRICULTURE AND BIOLOGY JOURNAL OF NORTH AMERICA

ISSN Print: 2151-7517, ISSN Online: 2151-7525, doi:10.5251/abjna.2012.3.12.516.524

(C) 2012, ScienceHuß, http://www.scihub.org/ABJNA

\title{
Review: List of arthropod pests and their natural enemies identified worldwide on date palm, Phoenix dactylifera $\mathrm{L}$.
}

\author{
H.A.F. El-Shafie \\ Date Palm Research Centre of Excellence, King Faisal University, P. O. Box 400, \\ Al-Hassa-31982, Kingdom of Saudi Arabia. e-mail: elshafie62@yahoo.com \\ ABSTRACT \\ The date palm, Phoenix dactylifera L. (Arecales: Arecaceae) is subject to damage by numerous \\ arthropod pests. This review lists 112 species of mite and insect pests associated with date palm \\ distributed among 10 orders and 42 different families. Of these species, few are identified as \\ major or potential pests of date palm tree. The listed species are classified according to their \\ preferred part on the tree into: 34 species on the foliages, 30 species on palm bases, stem and \\ roots, 26 species on inflorescences, bunch stalks, green and ripening fruits, and 22 species \\ attacking date during harvest and storage. In addition to harmful insect and mite pests, more than \\ 45 predators and parasitoids in 7 orders and 15 families are identified. Ten species are \\ considered as major pests viz., the red palm weevil (Rhynchophorous ferrugineus), Old world \\ date mite (Oligonychus afrasiaticus), lesser date moth (Batrachedra amydraula), Dubas date bug \\ (Ommatissus binotatus), green pit scale (Palmapsis phoenicis), carob moth (Ectomyelois \\ ceratoniae), longhorn date palm stem borer (Jebusaea hammerschmidti), rhinoceros beetle \\ (Oryctes agamemnon), fruit stalk borer (Oryctes elegans) and almond moth (Cadra cautella).
}

Key words: Date palm agro-ecosystem, data base, Phoenix dactylifera, predators and parasitoids, arthropod pests.

\section{INTRODUCTION}

Date palm (Phoenix dactylifera L.) is one of the oldest known fruit crops and has been cultivated in North Africa and the Middle East for at least 5000 years (78). The exact center of origin of date palm is unknown, but it is most likely originated from ancient Mesopotamia (Southern Iraq) or western India (75). From the center of origin, date palm cultivation spread throughout the Arabian Peninsula, North Africa, and the Middle East. Date palm culture had apparently spread into Egypt by the middle of the second millennium BCE, the spread of date palm cultivation later accompanied the expansion of Islam and reached Southern Spain and Pakistan. The Spanish were the first to introduce date palms outside the Arabian Peninsula, North Africa, , the Middle East, South Asia, carrying them to America (63). During the past three centuries, date palms were introduced to new production areas in Australia, India/Pakistan, Mexico, southern Africa, South America, and the United States (27). Arab countries possess $70 \%$ of the 120 million world's date palms and responsible for $67 \%$ of the global date production (33). The annual world production of dates is around 7.4 million tons and it has increased from approximately 2 million tons in 1962 to almost 7 million tons in 2005 (35). The 10 top date producing countries in the world are Egypt, Saudi Arabia, Iran, United Arab Emirates, Pakistan, Algeria, Sudan, Oman, Libya and Tunisia (50). Date palms are attacked by many pests and diseases and their nature and severity vary with cultivar, location, weather and cultural practices $(25,77)$. Factors that negatively affect date palm production, particularly in traditional date cultivation include crowding of trees, retention of old or unproductive trees, planting of mixed cultivars or seedlings, salt accumulation, poor drainage, insufficient irrigation, fertilization or tillage, lack of insect pests and diseases control, competition with other crops and weeds, soil degradation and water scarcity (26). The most comprehensive publication available on pests and diseases of date palm was given by Carpenter and Elmer (25) who reported 54 species of mite and insect pests of date palm worldwide. A more recent review on arthropod pests of date palm and their management in Israel was given by Blumberg (18) who reported 16 major and 15 minor species. Surveys of date palm insects were reported from Libya (14, 31, 57), Egypt (19), Palestine (11), Iraq (4, 22, 32), Qatar (3, 31), Kuwait, Bahrain and United Arab Emirates and Yemen (31), Sultanate of Oman (5), Saudi Arabia $(41,71)$, Pakistan (68), Sudan (73), Tunisia (29) and 
California, USA (28). The objective of this review is to make an updated, list of date palm mite and insect pests worldwide that can serve as baseline for more comprehensive data base. In this work, the date palm arthropods are classified into pests and natural enemies (predators and parasitoids). Pests are listed, according to their preferred part on the tree and economic importance, into 4 groups.

\section{Date palm mite and insect pests}

Pests of date palm leaves (rachis and pinnae): Table 1 summarizes the scientific and common names as well as the orders and families of the most important insect and mite pests of date palm leaves. The majority of the 34 listed species belong to the orders Homoptera and Coleoptera. Other orders of economic importance include Acari, Orthoptera and Thysanoptera. Green scale, red scale, and Parlatoria date scale are highly specific to the family Arecaceae (oligophagous) mainly found on foliage, bunch stalk and to less extent on green fruit, ripening fruits and shoots. Dubas date bug and Issid date bug are highly specific to date palm (monophagous). The former is mainly found on foliage, while the latter prefers shoots and/or palm bases with less tendency to be found on bunch stalk. Pineapple mealy bug is a Polyphagous species attaching a wide range of plants species and mainly found on ripening fruits (18).

Pests inflicting damage on palm bases, stem and roots: Thirty species in 4 orders and 11 families are listed as important pests of date palm bases, stem and shoot (Table 2). Red palm weevil and rhinoceros beetles are highly specific to the family Arecaceae. They can attack shoots and/or palm bases and stem (62). An emerging pest of date palm during the past decade is the red palm weevil which is threatening the date palm cultivation worldwide, and it is one of the most important areas of date palm research.

Mite and insect pests of inflorescences, bunch stalk, green and ripening: Yield components of date palm are damaged by numerous pests, some of them are considered very serious in different parts of the world. Twenty six species belonging to 8 orders and 15 families are listed in table 3 . The lesser date moth is highly specific to date palm and the most preferred organ is the green fruit. The old world date mite is oligophagous attacking mostly the green fruits. The greater date moth is oligophagous preferring bunch stalk and ripening fruits. Date stone beetle is highly specific to the family Arecaceae attacking green fruits (18). The old world date mite, Oligonychus afrasiaticus and the lesser date moth, Batrachedra amydraula are by far the most serious pests of developing date fruits

Insect pests attacking dates during harvest and storage: The Coleoptera and Lepidoptera are main two orders that contain 23 species of insect pests inflicting damage on date during harvest and storage (Table 4). The major insects of stored dates develop within the date fruit, therefore, need special consideration and prevention of infestation strategy is the best one to avoid contamination of fruits with the residues of insecticide fumigants. Treatment of dates on the bunches during April to June will effectively control the lesser date moth, date stone beetle and the greater date moth. This will affect positively the control of other ripe fruit moths and beetles particularly the sap beetle during August to late October (18). Management of date pests during this time of the cropping season will guarantee clean uninfested date in the storehouse. Precautions have to be taken to prevent re-infestation after storage and immigration of insects from outside the storage facilities.

Natural enemies of date palm pests: A list of predators and parasitoids of date palm pests recorded worldwide is shown in Table 5 . More than 45 species in 7 orders and 15 different families were reported. The predators account for more than 20 different species mainly in the family Coccinellidae while most of the parasitoids belong to the family Braconidae of the order Hymenoptera. Parasitic mites were also identified as potential antagonist in the date palm agro-ecosystem. It is important to give due consideration to these beneficial when launching control operations against date palm pests. Preharvest treatment of date pests with non-selective insecticides may lead to the buildup of resistance in insect population in addition to the extermination of their natural enemies leading eventually to insects' outbreaks. Selection of pesticide to control pests in the date palm agro-ecosystem should be done carefully to avoid the harmful effect of these chemicals on predators and parasitoids. Integrated pest management (IPM) should be recommended within the frame of integrated crop management (ICM) to achieve sustainability of date production. 
Table 1. Pests of date palm leaves (rachis and pinnae)

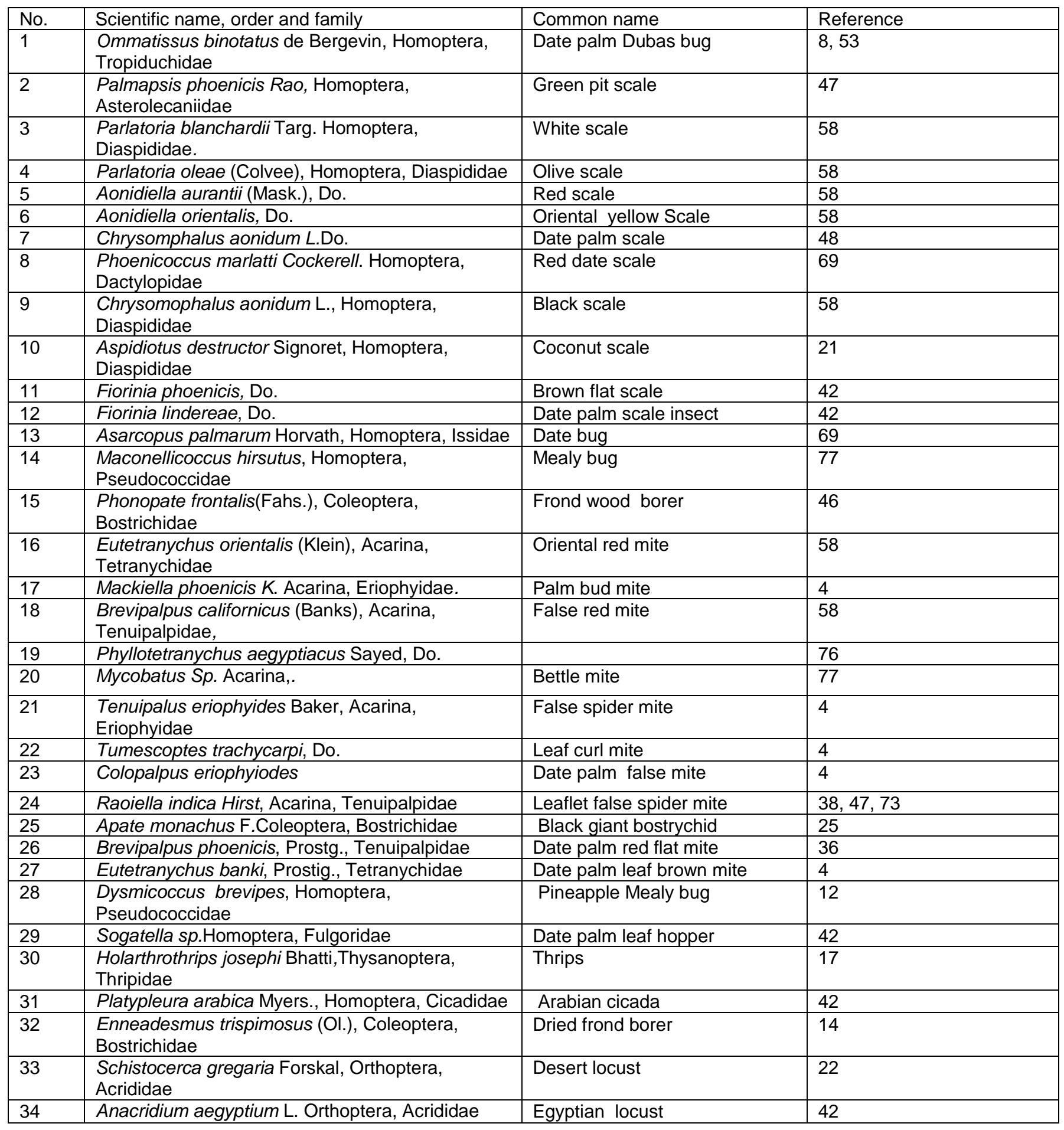


Table 2. Pests inflicting damage on palm bases, stem and roots

\begin{tabular}{|c|c|c|c|}
\hline No. & Scientific name, order and family & Common name & Reference \\
\hline 1 & $\begin{array}{l}\text { Rhynchophorus ferrugineus Olivier, Coleoptera, } \\
\text { Curculionidae }\end{array}$ & Red palm weevil & 39,62 \\
\hline 2 & $\begin{array}{l}\text { Jebusea hammerschmidti Reich } \\
\text { (syn. Pseudophillus testaceus), Coleoptera, } \\
\text { Cerambycidae }\end{array}$ & Longhorn date palm stem borer & 17 \\
\hline 3 & $\begin{array}{l}\text { Oryctes agamemnon Burmeister, Coleoptera, } \\
\text { Scarabaeidae }\end{array}$ & Fruitstalk or stem borer & 24,52 \\
\hline 4 & Oryctes boas Fabricius, Do. & Do. & 24 \\
\hline 5 & Oryctes sahariensis De Mire, Do. & Do. & 24 \\
\hline 6 & Oryctes elegans Prell, Do. & Do. & 24 \\
\hline 7 & Oryctes rhinoceros (Linnaeus), Do. & Do. & 24 \\
\hline 8 & Oryctes nasicornis prolixus (Wollaston), Do. & Do. & 24 \\
\hline 9 & Stratigus julianus Burmeister, Do. & Palm rhinoceros beetle & 42 \\
\hline 10 & $\begin{array}{l}\text { Apate monachus Fabricius, Coleoptera, } \\
\text { Bostrychidae }\end{array}$ & Black borer & 17 \\
\hline 11 & Dinapate wrightii Horn, Do. & Giant palm borer & 25 \\
\hline 12 & $\begin{array}{l}\text { Acanthophorus arabicus Thomson, Coleoptera, } \\
\text { Cerambycidae }\end{array}$ & & 17 \\
\hline 13 & $\begin{array}{l}\text { Microcerotermes diversus Silvestri, Isoptera, } \\
\text { Termitidae }\end{array}$ & Termites & 10,58 \\
\hline 14 & $\begin{array}{l}\text { Odontotermis sudanensis Sjöstedt, , Isoptera, } \\
\text { Termitidae }\end{array}$ & Do. & 64 \\
\hline 15 & Odontotermis smeathmani Ful., Do. & Do. & 73 \\
\hline 16 & Odontotermis obesus Rambur, Do. & Do. & 21 \\
\hline 17 & $\begin{array}{l}\text { Psammotermes hypostoma (Desneux), Isoptera. } \\
\text { Termitidae }\end{array}$ & Do. & 15 \\
\hline 18 & Amitermes stephensoni Harris, Do. & Do. & 42 \\
\hline 19 & Microtermes najdansis, Do. & Do. & 42 \\
\hline 20 & Ibostoma spp., Do. & Do & 25 \\
\hline 21 & Bellicositermes spp., Isoptera, Rhinotermitidae & Do. & 25 \\
\hline 22 & Coptotermes spp., Isoptera, Metatermitidae & Do. & 25 \\
\hline 23 & Gryllotalpa gryllotalpa L., Orthoptera, Gryllotalpidae & Mole cricket & 42 \\
\hline 24 & $\begin{array}{l}\text { Sphenophorus parampunctatus, Coleoptera, } \\
\text { Curculionidae }\end{array}$ & Date palm weevil & 77 \\
\hline 25 & $\begin{array}{l}\text { Rhynchophorus phoenicis Fabricius, , Coleoptera, } \\
\text { Curculionidae }\end{array}$ & African palm weevil & 77 \\
\hline 26 & Xyleborus perforans, Do. & Bark beetle & 42 \\
\hline 27 & Elaphidion villosum, Coloeptera, Cerambycidae & Stalk borer & 42 \\
\hline 28 & $\begin{array}{l}\text { Julodis spectabilis Cast-Gory, Coloeptera, } \\
\text { Buprestidae }\end{array}$ & Flat headed borer/date P. borer & 42 \\
\hline 29 & Julodis caillaudi Latr., Do. & headed borer/date P. borer & 42 \\
\hline 30 & Aspongopus viduatus F., Hemiptera, Pentatomidae & Black bug or water melon bug & 42 \\
\hline
\end{tabular}


Table 3. Mite and insect pests of inflorescences, bunch stalk, green and ripening fruits

\begin{tabular}{|c|c|c|c|}
\hline No. & Scientific name, order and family & Common name & Reference \\
\hline 1 & Oligonychus afrasiaticus McGreg, Acarina, Tetranychidae & Old world mite (Boufaroua) & $4,23,55,65$ \\
\hline 3 & Ectomyelois ceratoniae (Zeller), Lepidoptera, Pyralidae & Carob moth & 25 \\
\hline 5 & Coccotrypes dactyliperda Fab. Coleoptera, Curculionidae & Date seed beetle & $18,25,58$ \\
\hline 6 & Eutetranychus palmatus Attiah., Acarina, Eutetranychidae & Red spider mite & 9 \\
\hline 7 & Oligonychus pratensis Banks & Banks grass mite & 25 \\
\hline 10 & Polistes gallicus L.Do. & Spotted yellow wasp & 58 \\
\hline 11 & Vespa orientalis (L.), Hymenoptera, Vespidae & Oriental wasp & 48,58 \\
\hline 12 & Nipacoccous vastator (Mask.), Homoptera, Pseudococcidae & Spherical mealy bug & 58 \\
\hline 13 & Retithrips syriacus (Mayet.), Thysnoptera, Thripidae & Grape thrip & 58 \\
\hline 17 & Daralomus sp. Coleoptera, Curculionidae. & Inflorescence weevil & 58 \\
\hline 18 & Prionus unipectinatus White, Coleoptera, Cerambycidae & Inflorescence beetle & 17 \\
\hline 19 & Epicometis hirta (Poda), Coleoptera, Scarabaeidae & Flower chafer & 58 \\
\hline 20 & Potosia angustata Germar, Do. & Flower chafer & 48 \\
\hline 21 & Virachola livia Klug.Lepidoptera, Nymphalidae & Pomegranate butterfly & 58 \\
\hline 22 & Monolepta lepida Reiche, Do. & Green fruit beetle & 17 \\
\hline 23 & Antipa nigrocincta Lacordaire, Do. & Do. & 17 \\
\hline 24 & Dicerprocta apache (Davis), Homoptera, Cicadidae & Green-winged cicada & 34 \\
\hline 25 & Drosophila melanogaster Meigen, Diptera, Drosophilidae & Drosophila fly & 42 \\
\hline
\end{tabular}

Table 4: List of insect pests attacking dates during harvest and storage

\begin{tabular}{|l|l|l|l|}
\hline No. & Scientific name, order and family & Common name & Reference \\
\hline 1 & Ephestia cautella Walker, Lepidoptera, Pyralidae & Fig moth/Almond moth/ date moth & $25,61,70$ \\
\hline 2 & Tribolium castaneum (Herbst), Coloeptera, Tenebrionidae & Red flour beetle & 60 \\
\hline 3 & Tribolium confusum J.du V., Do. & Confused flour beetle & 60 \\
\hline 4 & Cryptolestes ferrugineus(Steph.), Coloeptera, Cucujidae & Rusty grain beetle & 25,47 \\
\hline 5 & Oryzaephilus surinamensis (L.), Coloeptera, Silvanidae & Saw-toothed grain beetle & 25,60 \\
\hline 6 & Oryzaephilus mercator (Fauv.), Coloeptera, Silvanidae & Merchant grain beetle & 25,60 \\
\hline 7 & Plodia interpunctella (Hubn.), Lepidoptera, Pyralidae & Indian meal moth & $25,30,60$ \\
\hline 8 & Arenipses sabella (Hmpsn), Lepidoptera, Pyralidae & Greater date moth & 25 \\
\hline 9 & Trogoderma granarium Ev., Coleoptera, Dermestidae & Khapra beetle & 47 \\
\hline 10 & Ephestia figulilella Gregson, Do. & Raisin moth & 1,22 \\
\hline 11 & Ephestia elutella Hubner, Do. & Tobacco moth & 22,60 \\
\hline 12 & Ephestia kuehniella (Zeller), Do. & Med. Flour moth & 22.47 \\
\hline 13 & Ephestia dowsoniella Richard, Do. & Dowson moth & 22,47 \\
\hline 14 & Ectomyelois ceratoniae (Zeller), Do. & The Carob moth & 25 \\
\hline 15 & Ephestia calidella Gunee, Do. & Currant moth & 60 \\
\hline 16 & Cotinis mutabilis Gary\& Percheron, Coloeptera, Scarabaeidae & The fig beetle & 25,58 \\
\hline 17 & Carpophilus hemipterus (F.), Coloeptera, Nitidulidae & Driedfruit beetle & 56,58 \\
\hline 18 & Carpophilus decipiens Horn., Do. & Dried fruit beetle & 56 \\
\hline 19 & Carpophilus dimidiatus (Fab.), Do. & Corn sap beetle & 56,58 \\
\hline 20 & Carpophilus mutilates, Do. & Confused sap beetle & 15,56 \\
\hline 21 & Urophorus humeralis (F.), Do. & Pineapple beetle & 15,56 \\
\hline 22 & Haptoncus luteolus (Erich.), Coloeptera, Nitidulidae & The yellowish nitidulid & 15,56 \\
\hline
\end{tabular}


Table 5. Predators and parasitoids of date palm insect and mite pests

\begin{tabular}{|c|c|c|c|}
\hline No. & Scientific name, order and family & Common name & Reference \\
\hline 1 & Chilocorus bipusrulatus, Coleoptera, Coccinellidae & Lady bird beetle & 47 \\
\hline 2 & Coccinella undecimpunctata, Coleoptera, Coccinellidae & Do. & 45 \\
\hline 3 & Coccinella quinquepunctata, Do. & Do. & 13 \\
\hline 4 & Coccinella septempunctata L., Do. & Do. & 45 \\
\hline 5 & Cryptolaemus montrouzieri, Do. & Do. & 59 \\
\hline 6 & Lobodiplosis pseudococci, Do. & Do. & 59 \\
\hline 7 & Scymnus unicatus Sicard, Do. & Do. & 59 \\
\hline 8 & Scymnus bipunctata, Do. & Do. & 16 \\
\hline 9 & Scymnus pictus Gorham, Do. & Do. & 18 \\
\hline 10 & Nephus bilucernarius Mulsant, Do. & Do. & 18 \\
\hline 11 & Rhyzobius lophanthae Do. & Do. & 40 \\
\hline 12 & Pharoscymnus anchorago, Do. & Do. & 69 \\
\hline 13 & Pharoscymnus numidicus Pic., Do. & Do. & 73 \\
\hline 14 & Pharoscymnus setulosus, Do. & Do. & 51 \\
\hline 15 & Pharoscymnus ovoideus, Do. & Do. & 51 \\
\hline 16 & Pharoscymnus pharoides, Do. & Do. & 51 \\
\hline 17 & Exochomus nigripennis (Erichson), Do. & Do. & 13 \\
\hline 18 & Leptomastix dactylopii Midwest, Hymenoptera, Encyrtidae & Tiny parasitic wasp & 13 \\
\hline 19 & Metaphycus sp., Do. & Do. & 73 \\
\hline 20 & Zeteticontus utilis Woyes, Do. & Do. & 18 \\
\hline 21 & Aphytis phoenicis, Hymenoptera, Aphelinidae & Aphelinid wasp & 54 \\
\hline 22 & Aphytis mytilaspides (Le Baron), Do. & Do. & 54 \\
\hline 23 & Trichogramma spp., Hymenoptera, Trichogrammitidae & Trichogramma parasitoid & 7 \\
\hline 24 & Bracon hebetor (Say), Hymenoptera, Braconidae & Braconid wasp & 13,49 \\
\hline 25 & Habrobracon hebetor (Say), Do. & Do. & 49 \\
\hline 26 & Venturia canescens (Gravenhorst), Hymenoptera, Ichneumonidae & Do. & 49 \\
\hline 27 & Phanerotoma flavitestacea Fish, Hymenoptera, Braconidae & Braconid parasitoid & 43 \\
\hline 28 & Phanerotoma ocuralis, Do. & & 43 \\
\hline 29 & Microctonus nitidulidis Loan, Do. & Braconid wasp & 18 \\
\hline 30 & Brachyserphus abruptus Say, Hymenoptera, Proctotrupidae & Proctotrupid wasp & 18 \\
\hline 31 & Parasierola swirskiana Argaman, Hymenoptera, Bethylidae & Parasitic wasp & 7 \\
\hline 32 & Tyrophagus sp., Acari., Acaridae & Parasitic mite & 4 \\
\hline 33 & Hypoaspis sp., Acari, Laelapidae, & Predatory mite & 4,66 \\
\hline 34 & Ameroseius sp., Acari, Ameroseiidae & Ameroseiid predatory mite & 4,66 \\
\hline 35 & $\begin{array}{l}\text { Cybocephalus nigriceps nigriceps (J. Sahlberg) ,Coleoptera, } \\
\text { Cybocephalidae }\end{array}$ & $\begin{array}{l}\text { Cybocephalid predatory } \\
\text { beetle }\end{array}$ & 16 \\
\hline 36 & Cybocephalus mediterraneus, Endrödy-Younga, Do. & Do. & 16 \\
\hline 37 & Cybocephalus aegyptiacus Endrödy-Younga, Do. & Do. & 16 \\
\hline 38 & Cybocephalus pullus Endrödy-Younga, Do. & Do. & 16 \\
\hline 39 & Cybocephalus micans, Reitter, Do. & Do. & 16 \\
\hline 40 & Crysoperla carnea, Neuroptera, Chrysopidae & Lace wing & 13 \\
\hline
\end{tabular}


Agric. Biol. J. N. Am., 2012, 3(12): 516-524

\begin{tabular}{|l|l|l|l|}
\hline 41 & Archenomus arabicus Ferriere, Hymenoptera, Aphelinidae & Aphelinid wasp & 51 \\
\hline 42 & Hemisacoptes coccophagus (Meyer) & Predacious mite & 37 \\
\hline 43 & Chelisoches morio F., Dermaptera, Forficulidae & Earwig & 2 \\
\hline 44 & Anisolabis maritime, Do. & Do. & 6 \\
\hline 45 & Scolia erratica (Smith), Hymenoptera, Scoliidae & Parasitic wasp on RPW & 29,62 \\
\hline 46 & Tetrapholypus rhynchophori, Acarina, Pyemotidae & Parasitic mite on RPW & 67 \\
\hline 47 & Platymeris laevicollis Distant, Hemiptera, Reduviidae & Predatory bug & 67 \\
\hline 48 & Sarcophaga fuscicauda Bottcher, Diptera, Sarcophagidae & Parasitic fly & 74 \\
\hline 49 & Xylocoris galactinus Fieber, Hemiptera, Anthocoridae & Athocorid predator & 6 \\
\hline
\end{tabular}

\section{CONCLUSIONS:}

In this review, arthropod pests of date palm are classified into 4 groups based on their preferred date palm organ. attacked, However some species are not highly specific may infest more than one part at the same time. For example, green and white scales prefer the foliages but, they attack green or ripening fruits depending on many factors including severity of infestation and prevailing weather conditions. The interaction among the date palm pests is enormous. For example, the lesser date moth is mainly pest of green fruits that leads to fruit dropping which encourage the build-up of the sap beetle populations. The damage caused by rhinoceros and longhorn stem borer might facilitate the attack by the red palm weevil. The date palm trees weakened by scale insects and other sucking pests may dispose the tree to attack by termites and other pests. Poor management like no pruning, lack or excess of irrigation and fertilization will predispose the date palm tree to infestation by insect and mite pests. Specific insect problems vary with geographic area and poor field sanitation may also aggravate the situation and lead to the increase of specific pest population. Chemicals, biological control, pheromone trapping, quarantine and sanitation practices are used to control insect pests of date palm (44). Mineral oils, IGRs, pyrethroids, carbamates, nicotinoids and acaricides which are environmentally friendly and have less toxicity to humans can be used as selective compounds against date palm pests (18). The area of date production in the Arabian Peninsula and the Middle East has increased dramatically during the past few decades and is expected to continue to increase (27). The list of date palm pests has increased from 54 species of mite and insect pests in 1978 (24) to 112 species in 2012 as reported in this review. More pests are expected to emerge as a result of the worldwide expansion in date palm cultivation. Planting of tissue culture seedlings and strict quarantine measures should be adopted to avoid the transportation of insect and mite pests of date palm into new areas. Control strategies based on short-term chemical campaigns could interrupt the natural regulation of date palm pests by their predators and parasitoids and eventually change minor species into major ones.

\section{REFERENCES}

1. Abou El-Ghar, M. R. and M. S. El-Rafie. (1964). Control measures of date pests in Egypt. Bull. Soc. Entomol. Egypte.48: 291-301.

2. Abraham, U.A., Kurian, C. and Nayer, N.M. 1973. Chelisoches morio F. ( Forficulidae, Dermaptera) a predator on eggs and early instar grubs of the red palm weevil, Rhynchophorus ferrugineus. Journal of Plantation Crops. 1, 147-152.

3. Al-Azawi, A.S. 1986. A survey of insect pests of date palm in Qatar. Date palm J. 4 (2): 247-266.

4. Al-Jboory, I.J. 2007. Survey and identification of the biotic factors in the date palm environment and its application for designing IPM-program of date palm pests in Iraq. Univ. Aden J. Nat. and Appl. Sci. 11, 3, 3-10 (In Arabic).

5. Aly, A.G. and Elwan, A. 1995. Survey of insect pests and mites infesting palm trees in Oman Sultanate, Egypt J. Appl. Sci, 10 (4): 261-264.

6. Anonymous, 2001. Fifth Annual Report on Biological Control of the red palm weevil project in Gulf countries. Dubai, United Arab Emirates.

7. Argaman, Q. 1991-1992. Parasierola swirskiana n. sp. (Hymenoptera: Bethylidae) from the lesser date moth, Batrachedra amydraula Meyerick (Lepidoptera: Batracheridae). Isr. J. Entomol. 25-26: 195-198.

8. Asche, M. and Wilson, M.R. 1989. The palm-feeding planthopper genus Ommatissus (Homoptera: Fulgoroidea: Tropiduchidae). Syst. Entomol. 14: 127147.

9. Attiah, H.H. (1967). The genus Eutetranychus in the U.A.R, with description of three new species (Acarina: Tetranychidae). Bull.Soc. Entomol. Egypte 51:11-16

10. Avidov, Z. and Harpaz, I. 1969. Plant pests of Israel. Israel Universities Press, Jerusalem, Israel. 
11. Ben-Dov, Y. 1985. Further observation on scale insects (Homoptera: Coccoidea) of the middle East. Phytoparasitica, 13(3-4): 185-192.

12. Ben-Dov, Y. and Miller, D.R., 2007. ScaleNet, a systemic database of the scale insects of the world. http://www.sel.barc.usda.gov/scalenet.htm

13. Bitaw, A.A. and Ben Saad, A.A. 1990 a . Survey of natural enemies of date palm pests in Lybia. Arab J. Plant prot. 8 (1): 12-15.(In Arabic with English Abstract).

14. Bitaw, A.A. and Ben Saad, A.A. 1990 b. Survey of date palm tree insect pests in Lybia. Arab J. Plant prot. 8 (2): 72-76.

15. Bitton, S., Nakash, Y., Soroker, V. and Blumberg, D. 2007. Control trials of sap beetle in date plantation. Alon Hanotea 62:974-977.

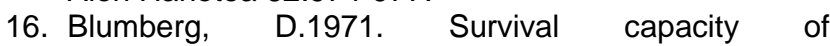
Cybocephalous spp. (Coleoptera: Cybocephalidae) under temperature and humidity extremes. Entomol. Exp. Appl. 14: 434-440.

17. Blumberg, D. 2004. Date palm pests and their control measurement in: Bernstein, Z. (Ed.)\{Date growing In Israel\} The plant production and marketing board, telAviv., Isreal, pp.398-433.

18. Blumberg, D. (2008). Review: Date palm arthropod pests and their management in Israel. Phytoparasitica 36(5): 411-448.

19. Bodenheimer, F.S. 1923. Observations about some scale insects form El-Arish (Sinai) and Transjordania. Bull. Soc.R.ent. Egypt. 16: 121-124.

20. Burkill, I.H. 1917. Scolia erratica (Smith) a parasite of the red coconut weevil, Rhynchophorus ferrugineus, Garden Bulletin, 1, 399-400.

21. Butani, R.K. 1974. Les insectses Parasites Du palmierDattier en Inde et leur Controle. Fruits 29: 689-691.

22. Buxton, B.A. 1920. Insect pests of date and date palm in Mesopotmia and elsewhere, Bull. Entomol. Res., 11: 287-303.

23. Calcat, A. (1959). Diseases and pests of date palm in the Sahara and North Africa. Bull. Entomol. Res. 11: 287-303.

24. Carpenter, J.B. 1975b. Notes on date culture in the Arab republic of Egypt, Israel and the people's democratic republic of Yemen. Date Growers' Inst. Rep. 52: 18-24.

25. Carpenter, J.B. and Elmer, H.S. (1978). Pests and diseases of the date palm. U.S.Dep. Agric. Handbk. 527: 1-42

26. Carpenter, J.B. 1981. Improvement of traditional date culture. Date palm J. 1: 1-16.

27. Chao, C. and Krueger, R. 2007. The date palm (Phoenix dactylifera L.) : Overview of Biology, Uses and Cultivation, HortScience 42 (5) : 1077-1082.

28. Cook, A.J.1914. The date scate. Monthly, Bull. Cal. State. Commiss. Hortic., Sacramento, 4(10): 440-441. (cf. R.A.E, 3:84).

29. Dhouibi, MH. 1991. Les principaux ravageurs des palmiers dattier et la date en Tunisie. Institut National Agronomique de Tunisie.
30. Donahaye E., and Calderon, G. H. (1964). Survey of insects infesting dates in storage in Israel. Israel $\mathrm{J}$. Agric. Res. 14:97-100.

31. El-Haidari, H.S. 1981. New records of mites and insects infesting date palms in the Near East and North Africa. Date palm J., (1): 133-136.

32. El-Haidari, H.S; El-Bana, M.M. and Khudhair, S.A. 1981. New records of insects attacking date palm treated with growth regulators in Iraq, Date palm J., $1(1): 134-135$.

33. Juhany, L. I. 2010. Degradation of date palm trees and date production in Arab countries: causes and potential rehabilitation, Australian $\mathrm{J}$. of basic and applied sciences, 4(8): 3998-4010.

34. Elmer, H.S. 1963. Protection of dates from injury caused by the Apache cicada in California, J.Econ. Entomol. 56: 875-876.

35. Food and Agriculture Organization of the United nations. 2006. Worldwide dates production statistics. 19 mar.2006. http:// faostat/servlet.

36. Gentry, J.W. 1965. Crop insects of Northeast AfricaSouth-west Asia, U.S. Dep. Agric. Agric. Res. Serv. Agric. Handb. 273.

37. Gerson, U. and Smiley, R.L. 1990. Acarine Biocontrol Agents, an illustrated key and manual. Chapman and Hall, London, UK.

38. Gerson, O., Venezian, A. and Blumberg, D. (1983). Phytophagous mites on date palms in Israel. Fruits; 38: 133-135

39. Giblin-davis, R. M. (2001). Borers of palms. In: Howard, F. W., Moore, D., Giblin-davis, R. and Abad, R.G. \{Eds.\} Insects on palms. CABI publishing, Wallingford, UK. Pp. 267-305.

40. Gomez, S. V. 2002. Cŕa masiva de Rhyzobius lophanthae Blaisdell (Coleoptera: Coccinellidae) de predator de la Cochinilla roja de las palmeras (Phoenicococus marlatti Cockerell) Bol. San. Veg. Plagas 28: 167-176.

41. Hammad, S.M. and Kadous, A.A. 1989. Studies on the biology and ecology of date palm pests in the Eastern province, Kingdom of Saudi Arabia. Pp.145, King Abdul-Aziz City for Science and Technology.

42. Hassan, N., Thuraya, A. and Al-Buraidi, F.H. 1986. A list of Date palm pests and their economic importance in Saudi Arabia. Proceeding of the $2^{\text {nd }}$ Symposium on the date palm in Saudi Arabia, March 3-6,(2): 345-356. Date palm research center, King Faisal University, AlHassa, Mars Publishing house, Riyadh, Saudi Arabia.

43. Hassan, B., Chemseddine, M., Abbassi, M. and Brun, J. 2001. The date moth in the area of Tafilalet in the Southeast of Morocco. http://webspirs.ziur.co.il/webspirs/doLS.ws?ss= FruitsParis+ in + So 56: 189-196 ( In French).

44. Howard, F.W., Moore, D., Giblin-Davis and Adad, R.G. 2001. Insects on palms. CAB international, Wallingford, UK.

45. Hussain, A.A. 1963a. Biology and control of the Dubas bug, Ommatissus binotatus lybicus De Berg 
(Homoptera : Tropiduchidae) infesting date palm in Iraq. Bull. Entomol. Res. 53: 737-745.

46. Hussain, A.A. 1963b. Notes on borers of date palms in Iraq. Bull. Entomol. Res. 54: 345-348.

47. Hussain, A.A. (1974). Date palms and dates with their pests in Iraq. Ministry of Higher education and scientific research, University of Baghdad, Baghdad, Iraq.

48. Izhar, Y., Wysoki, M., Blumberg, D. and Swieski, E. 1997. The flower chafer Potosia angustata Germar (Coleoptera: Scarabaeidae), a pest of Lchee, pear, avocado and date palm in Isreal. Alon Hanotea, 51: 60-62 (In Hebrew with English abstract).

49. Johnson, J.A., Valero, K.A., Hannel, M.M. and Gill, R.F. 2000. Seasonal occurrence of postharvest dried fruit insects and their parasitoids in a culled fig warehouse. J.Econ. Entomol. 93: 1380-1390.

50. Kader, A.A. and Hussein, A.M. 2009. Harvesting and Post-harvesting handling of dates. International Center for Agricultural Research in the Dry Areas (ICARDA).

51. Kehat, M. 1967. Some notes on the life cycle of the date palm scale, Parlatoria blanchardi Targ in Israel. Israel J. Agric, Res. 17: 175-179.

52. Khoualdia, O. Rhouma, A, Marro, JP and Brun J. 1997. Premieres observations sur Oryctes Agamemnon (Col.,: Scarabidae), nouveau ravageur du palmier dattier en Tunisie. Fruits 52: 111-115.

53. Klein, M. and Venezian, A. 1985. The dubas date, Tropiduchid, Ommatissus binotatus lybicus, a threat to date palms in Israel. Phytoparasitica, 13: 96-101.

54. Laudeho, Y. 1968. Aphites mytilaspides (Le Baron) Parasite de Parlatoria blanchardi Targ. Dans les Palmeraies de L'Adrar Mauritanien. Fruits 23: 271-275.

55. Lepesme, P. (1947). Les insects des palmiers. Editions $P$. lechevalier, Paris, France

56. Lindgren, D. L. and Vincent, L.E. (1953). Nitidulids beetles infesting California dates. Hilgardia 22: 97-118.

57. Martin, H. 1958. Pests and diseases of date palm in Libya, FAO plant prot. Bull., 6 (8): 120-123.

58. Mashal, M. and Albeidat, B. 2006. A survey on insect pests of date palm trees in Jordan (Research Note). Jordan J. Agric. Sci. 2 (1): 94-104.( In Arabic with English abstract).

59. Mau, R.F.L. and Kessing, J.L.M, 2007. Dysmicoccus brevipes

(Cockerell).http://www.extent.hawaii.edu/kbase/crop/Ty pe/d_brevip/htm

60. Mohammed M. Ziat, Al-Giat, S.I., Logma, H.I., Dhafran, H.A., Al-Abdelsalam, K.S.[Eds.] (2002). Important diseases and pests of date palm and their integrated control in the Kingdom of Saudi Arabia. FAO, 369 pp. (in Arabic)

61. Moore, D. (2001). Insects of palm flowers and fruits. In: Howard, F. W., Moore, D., Giblin-davis, R. and Abad, R.G. \{Eds.\} Insects on palms. CABI Publishing, Wallingford, UK. pp. 233-266.
62. Nirula, K. K. 1956. Investigations on the pests of coconut palm. Part 4. Rhynchophorus ferrugineus. Indian coconut Journal, 9, 229-247.

63. Nixon, R.W. 1951. The date palm: "Tree of Life" in the subtropical deserts. Econ. Bot. 5: 274-301.

64. Nixon, R.W. 1967. Date culture in Sudan. Date Growers' Inst, Rep. 44: 9-14.

65. Palevsky, E., Borochov-Neori, H. and Gerson, U. 2005. Population dynamic of Oligonychus afrasiaticus in the Southern Arava Valley of Israel in relation to date fruit characteristics and climatic conditions. Agric. For. Entomol. 7: 283- 290.

66. Peter, C. 1989. A note on the mites associated with the red palm weevil, Rhynchophorus ferrugineus Olivier in Tamil Nadu, J. Insect Sci. 2: 160-161.

67. Reginald, C. 1973. Principal insect pests in coconuts. Tropical Agriculture Series, Longmans, London, UK.

68. Sharif, M. and Wajih, I.C. 1982. Date palm pests and diseases in Pakistan, Proc. $1^{\text {st }}$ Symposium on the date palm, King Faisal University, Al-Hassa, Saudi Arabia, March 23-25, P: 440-451.

69. Stickney, F.A., Barres, D.F. and Simmons, P. 1950. Date palm insects in the united states, U.S. Dep. Agric. Circ. 846, $52 \mathrm{pp}$

70. Swirski, E., Wysoki, M. and Izhar, Y. 2002. Subtropical fruit pests in Isreal. Fruit board of Israel, Tel-Aviv., Isreal (Hebrew with English preface).

71. Talhouk, A.S. 1982. The present status of date palm pests in Saudi Arabia. ibid: 432-438.

72. Talhouk, A.S. (1991). On the management of the date palm and its arthropod enemies in the Arabian Peninsula. J. Appl. Entomol. 111: 514-520.

73. Yousof, D.E. 2010. Insect and mite pest species and some insect natural enemies on date palm in the Northern State, Sudan. MSc. Thesis, Sudan Academy of Sciences, Khartoum, Sudan.

74. Venkatasubbaiyer, C. S. 1994. Two interesting and unrecorded enemies of the red palm weevil Rhynchophorus ferrugineus, Indian Journal of Entomology 2, 98.

75. Wrigley, G, 1995. Date Palm, p.399-403, In: J. Smartt and N.W. Simmonds (eds.). Evolution of crop plants. $2^{\text {nd }}$ ed. Longman Group, Essex, UK.

76. Zaher, M. A., Wafa, A.K. and Yousef, A.A. 1969. Biological studies on Rhyllotetranychus indica Hirst and $R$. aegyptiacus Say infesting date palm trees in the U.A.R. (Acarina: Tenuipalpidae), Z. Angew. Entomol. 63: 406-411.

77. Zaid, A., de Wet, P.F., Djerbi, M. and Oihabi, 2002. Diseases and pests of date palm, p.227-281. In: Zaid, A. (ed.), Date palm cultivation. Food and Agriculture Organization. Plant production and protection paper no. 156. Food and Agriculture organization of the United Nations, Rome, Italy.

78. Zohary, D. and Hopf, M. 2000. Domestication of palms in the old world: the origin and spread of cultivated plants in West Asia, Europe, and the Nile Valley. Oxford University press, Oxon, UK. 